\title{
Impact of Employee Involvement on Organizational Effectiveness in the Banking Sector in Kerala
}

\author{
Kochuthresia Mathew ${ }^{1}$, Resmi $\mathbf{R}^{2}$ \\ ${ }^{1}$ Research Scholar, PG and Research Dept. of Commerce, Maharaja's College, Ernakulam \\ (MG University, Kottayam) \\ ${ }^{2}$ Assistant Professor, SSV College, Valayanchirangara, Perumbavoor
}

Corresponding Author: Kochuthresia Mathew

\begin{abstract}
It's a common knowledge that every business organization depends on its effective functioning of human resources. Employee involvement and analysis of banking efficiency has received increasing attention in applied economics in recent years due firstly, to the rapid globalization of the financial industry and secondly, to increasing competitiveness in international financial markets. Analyzing the operational efficiency of banks in India to ascertain how efficiently they perform their basic functions. The effectiveness of each organization is based on its performance of human resources. The present study was conducted to identify the level of involvement of employees in order to achieve the effectiveness of banking sector in Ernakulam District of the state of Kerala. For this purpose, responses of 367 employees selected using stratified random sampling from six commercial banks.
\end{abstract}

Keywords: Employee Involvement, Organizational Effectiveness

\section{INTRODUCTION}

One of the greatest underlying factors in the success or failure of any organization is the power of its people, and how well that power is focused towards meeting the organization's objectives. It is a common knowledge that every business organization depends on its effective functioning of human resources. The importance of this factor is due to its unique characteristics. Like, this is the only resource which is able to produce an output greater than its input. All companies operate on the strengths and weaknesses of their employees. Even in a fully automated factory, employees have to design, maintain, and operate the systems that create output. Organizations that can tap the strengths of their people will be stronger and more competitive than those that cannot (Cooper, 2011). Organizations that regard people as automatons or mere cogs in a wheel will never realize their full potential. In the long run, such companies' inefficiencies attract competition, and unless the management philosophy changes, they will disappear. Employee involvement is a process for empowering employees to participate in managerial decision-making and improvement activities appropriate to their levels in the organization. Since McGregor's Theory Y first brought to managers the idea of a participative management style, employee involvement has taken many forms, including the job design approaches and special activities such as quality of work life (QWL) programs (Bond, 2004).

There is at the end of the day only one thing that differentiates one company from another-its people. Not the product, not service establishments, not the process, not secret ingredients; ultimately any of these can be duplicated. The Japanese have always recognized this and it is one of the reasons for their success in world marketsthey place tremendous value on the 
integration of people with organizational objectives, equipment and processes. The employees force the organizations to address three key issues; communication, involvement and development. In fact the three issues can be used as a measure of an organization's maturity in the employment relationship. Here, we are going to address the issue of involvement and its relationships. Many people confuse communication systems such as team briefings with involvement (Ahiauzu, 2011).

Involvement, however is more than just the exchange of information. It is the gradual but radical delegation of control to those closest to the process itself. Selfmanaged teams, cell-based manufacture, autonomous work groups, high performance work systems, are all examples of true involvement. The best way to obtain a genuine commitment from people is to involve them in the project from the beginning. Organizations operating with the involvement of their employees, have evolved beyond merely telling people what is going on, to actively seeking their contribution to the decision making process (Tesluk, 1999). Only a minority of organizations in industry could be truly said to be operating with the involvement of their employees, but the trend over the last 10 years has certainly been to move towards this direction, often following the link of inward investors such as the Japanese, Germans and Americans, and the opportunities presented by reconstruction and Greenfield sites.

The success of a bank depends on its strategy for customer acquisition and retention. On its ability to get into the minds of the consumers, analyzing their requirements and translating these into effective operating models. For getting consumers regularly, the banks have to concentrate on its effectiveness. Effectiveness of every organization is depends on the work environment, commitment of employees, job satisfaction and most importantly on employee involvement. Employee involvement means that every employee is regarded as a unique human being, not just a cog in a machine and each employee is involved in helping the organization to meet its goals. Employee involvement is a process of engaging employees also to the decision making process (Sarangi, 2012). The Reserve Bank of India, India's central banking authority, was established in April 1935, but was nationalized on 1 January 1949 under the terms of the Reserve Bank of India Act 1948. In 1949, the Banking Regulation Act was enacted which empowered the Reserve Bank of India (RBI) to 'regulate, control and inspect the banks in India'. In the early 1990s, the government embarked on a policy of liberalization, licensing a small number of private banks. These came to be known as New Generation Tech-Savvy Banks and included Global Trust Bank which later amalgamated with Oriental Bank of Commerce, UTI Bank (since renamed as Axis Bank), ICICI Bank and HDFG Bank. This move, along with the rapid growth in the economy of India, revitalized the Banking Sector in India, which has been rapid growth with strong contribution from all the three sectors of banks namely, government banks, private banks and foreign banks. Then Indian Banking has been set up with the proposed relaxation in the norms for foreign direct investment (Gupta, 2013).

\section{REVIEW OF LITERATURE Employee Involvement}

(Edward, 2009) analyzed whether employee involvement makes a difference and whether there is an increase in the use of employee involvement from 1987 to 1996. The author found that, all involvement is a substantial change in the basic structure of the organization and is aimed at moving important operating discussions into the hands of individuals. (Sarangi, 2012) examined the employee engagement initiatives in Indian banking sector that, employee engagement is a force 
that motivate employees to the higher level of performance and it gives commitment, loyalty, productivity and ownership to the organization. (Judeh, 2011) revealed in a study on 'An examination of the effect of employee involvement on teamwork effectiveness: An empirical study' that, employee involvement has been linked to many different management concepts and behaviors such as management style, total quality management, employee empowerment, job satisfaction and job performance. (Toomey, 2006) analyzed in the study on 'Employee involvement teaming in the material review and corrective action group' and found that, employee involvement and employee satisfaction are directly related to customer satisfaction and business success. (Zwick, 2008) revealed in a study on 'Reassessing the productivity impact of employee involvement and financial incentives' that, employee involvement and financial incentives are often praised as effective means for increasing firm's productivity. (Pekovic, 2013) revealed that, employee involvement is a crucial element of the successful quality standard implementation. And also employee involvement is a potential mediator of the relationship between quality standard and employee outcomes.

\section{Organizational Effectiveness}

(Khan, 2012) found that, banking is one the most important and significant business all over the world. Job training is a better tool for organizational effectiveness. (Singh, 2013) revealed that, empowering the line managers with greater responsibility in terms of day to day HR affairs can reduce employee turnover and improve organizational effectiveness. (Dogbe, 2011) examined pay as a motivational tool for achieving organizational performance. The study shows that, in many developed economies, there has been an increased interest on performance related pay (PRP) to develop their organizational performance. (Verma, 2013) in this study organizational change effectiveness in an Indian public sector organization found that, an effective work environment is vital to the success of small business and large corporations. The quality of employee relationship plays an important role in promoting employee acceptance and involvement. (Foley, 2012) explored the rhetoric and reality of performance management system and organizational effectiveness-Evidence from Australia'. This study stated that, aligning business and HRM strategy leads to improved organizational performance and effectiveness. (Srivastva, 2009) analyzed in this study of Locus of control as a moderate for relationship between organizational role stress and managerial effectiveness found that, organizational effectiveness is nothing more than the output and it is dependent upon the output with regards to one's position in the organization. An effective manager is an optimizer of resources for better organizational effectiveness.

\section{Objectives}

1. To identify the factors affecting involvement of employees among executives and non-executives in the Banking sector.

2. To analyze the factors affecting organizational effectiveness through employee involvement.

3. To examine the relationship between employee involvement and organizational effectiveness in the Banking sector.

\section{METHODOLOGY}

In this study, the impact of involvement of the employees in each category is assessed and also analyzed the overall effectiveness of the organization. The population of the study includes employees in commercial bank in Kerala only. It include different category of employees in different banks like managers, officers and clerks. In Kerala, Ernakulam district was selected as the sample area of the study. The reason behind to selecting the district as the sample area because the district became India's first district having 100 percent banking in 2012 (The Hindu 
2015). This District is dedicated to the nation as the first one having meaningful financial inclusion. Moreover, there are many nationalized banks, private sector banks, foreign banks and regional rural banks functioning in this district, considering the number of branches and number of employees. State Bank of India, Punjab National Bank, Federal Bank, South Indian Bank, ICICI Bank and HDFC Bank were selected for the study.

For the present study, only the number of branches and the number of employees in the Ernakulam district were considered. Then the bank branches and the number of employees selected are not with an idea of giving proportional representation. From each of the banks selected for the study, $10 \%$ of branches are selected at random, the total number of branches being 39. From each bank the number of executives and non-executives were selected in 1:2 ratio. The size of the sample for the study was determined by using a 'Sample Size Calculator' from SurveyMonkey. According to this calculator, the sample is 367 .

The statistical tools used for the primary analysis were Correlation, Factor Analysis for factor reduction and linear regression analysis.

Statistical Analysis

To analyze the factors which are affecting the employee involvement in the Banking sector, the present study use Structural Equation Modelling (SEM).

Analysis of Factors Affecting Employee Involvement

\section{Hypotheses:}

$\mathbf{H}_{0}$ : Construct EI 1 to EI 10 has no impact on employee involvement.

$\mathbf{H}_{1}$ : Construct EI 1 to EI 10 has significant impact on employee involvement.

Model fit indicates For CFA Employee Involvement

\begin{tabular}{|c|c|c|c|c|c|c|c|c|c|c|c|}
\hline Factor/ Variable & $\chi^{2}$ & DF & P & Normed $\chi^{2}$ & GFI & AGFI & NFI & TLI & CFI & RMR & RMSEA \\
\hline Employee involvement & 24.516 & 20 & .221 & 1.226 & .987 & .963 & .969 & .986 & .994 & .031 & .025 \\
\hline
\end{tabular}

All the attributes loaded significantly on the latent constructs. The value of the fit indices indicates a reasonable fit of the measurement model with data

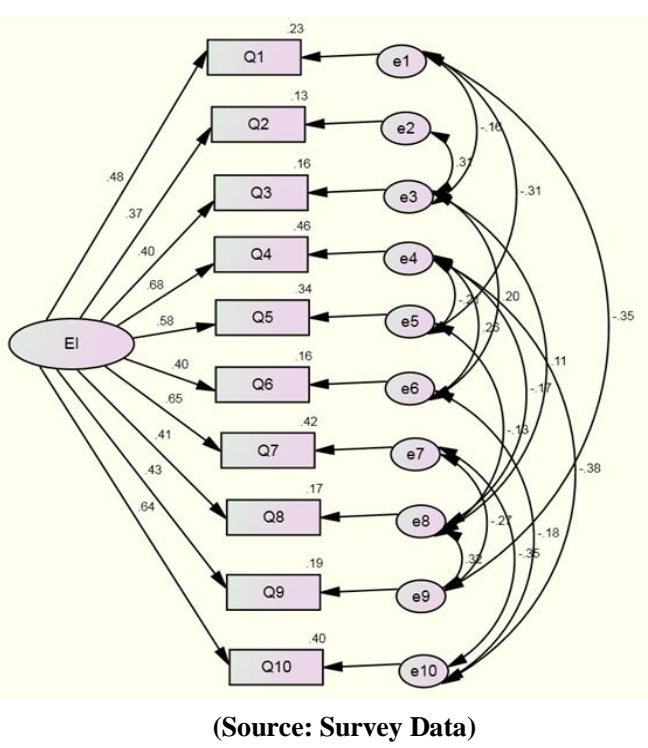

The above AMOS 18.0 graphics described that, the rectangle represents the observed variables which were; selfanalysis, motivation, collaboration, involvement, flexibility, consultation, self-
Factors influencing Employee Involvement

\begin{tabular}{|c|c|c|}
\hline Dependent Variables & Constructs & Factors \\
\hline \multirow{5}{*}{ Employee Involvement } & Q1 & Self- analysis \\
\cline { 2 - 3 } & Q2 & Motivation \\
\cline { 2 - 3 } & Q3 & Collaboration \\
\cline { 2 - 3 } & Q4 & Involvement \\
\cline { 2 - 3 } & Q5 & Flexibility \\
\cline { 2 - 3 } & Q6 & Consultation \\
\cline { 2 - 3 } & Q7 & Self- satisfaction \\
\cline { 2 - 3 } & Q8 & Self- achievements \\
\cline { 2 - 3 } & Q9 & Self- knowledge \\
\cline { 2 - 3 } & Q10 & Self- worth \\
\hline
\end{tabular}

satisfaction, self- achievements, selfknowledge and self- worth. The ovals shown in the graphics are unobserved variables like; e1, e2, e3.....e10. The curved double headed arrows represent 
Kochuthresia Mathew et.al. Impact of employee involvement on organizational effectiveness in the banking sector in Kerala

correlation among the unobserved variables. And also the straight headed arrows represent the factor loadings of the observed variables. Therefore, the graphics explained that, most of the observed variables have significant impact with 'employee involvement', because the value is greater than 0.4. While one observed variable has no impact with employee involvement, because, its value is less than 0.4. The graphics also described that, the highest correlation among unobserved variables is 0.31 with e 2 and e3. At the same time, the less correlation is between unobserved factors of e4 and e10 with 0.11 .

Analysis of Factors Affecting Organizational Effectiveness

\section{Hypotheses:}

$\mathrm{H}_{0}$ : Construct $\mathrm{OE} 1$ to $\mathrm{OE} 16$ has no impact on organizational effectiveness.

$\mathrm{H}_{1}$ : Construct $\mathrm{OE} 1$ to $\mathrm{OE} 16$ has significant impact on organizational effectiveness.

Model fit indices for CFA of Organizational Effectiveness

\begin{tabular}{|c|c|c|c|l|l|l|l|l|l|l|l|}
\hline Factor/ Variable & $\chi^{2}$ & DF & P & Normed $\chi^{2}$ & GFI & AGFI & NFI & TLI & CFI & RMR & RMSEA \\
\hline Organizational effectiveness & 107.697 & 57 & .000 & 1.889 & .966 & .918 & .970 & .969 & .985 & .296 & .049 \\
\hline \multicolumn{10}{c|}{ (Source: Survey Data) }
\end{tabular}

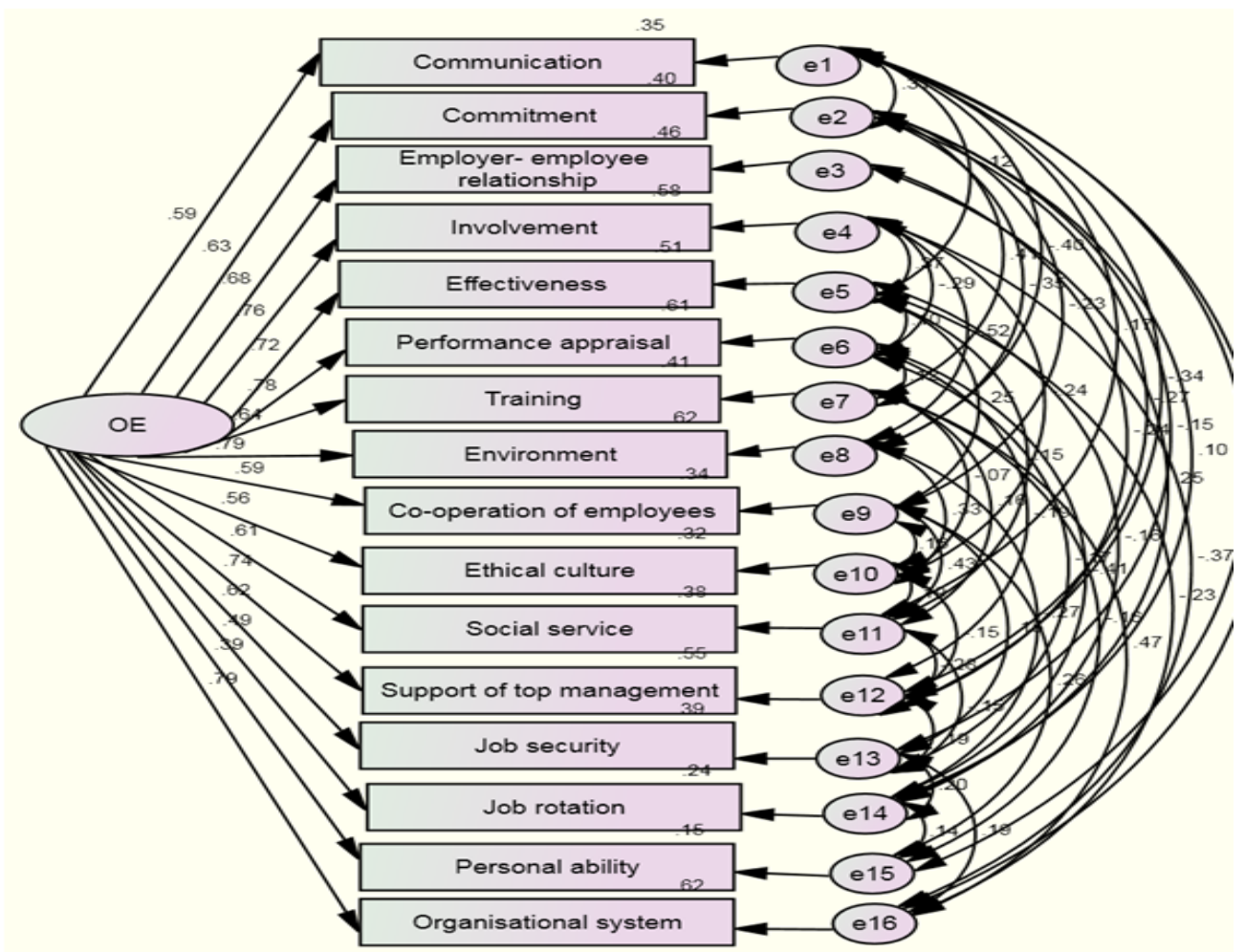

The AMOS 18.0 graphics explained that, except the observed variable personal ability, all other observed variables have significant impact on organizational effectiveness, because, the value of all that variables is greater than0.4. But, in the case of personal ability, because of its value which is less than 0.4 , has no impact on organizational effectiveness
Analysis of Relationship Between Employee Involvement And Organizational Effectiveness

\section{Hypotheses:}

$\mathrm{H}_{0}$ : There is no relationship between employee involvement and organizational effectiveness.

$\mathrm{H}_{1}$ : There is significant relationship between employee involvement and organizational effectiveness.

Correlation between Employee Involvement and Organizational Effectiveness

\begin{tabular}{|c|c|c|c|c|c|}
\hline Variables & Correlation & Lower bound & Upper bound & $\mathbf{Z}$ & $\mathbf{p}$ \\
\hline Organizational effectiveness-Employee involvement & 0.513 & 0.487 & 0.539 & 11.418 & 0.000 \\
\hline
\end{tabular}


Kochuthresia Mathew et.al. Impact of employee involvement on organizational effectiveness in the banking sector in Kerala

Model fit indices

\begin{tabular}{|c|c|c|c|c|c|c|c|c|c|c|c|}
\hline \multicolumn{1}{|c|}{ Factors } & $\boldsymbol{\chi 2}$ & $\mathbf{D F}$ & $\mathbf{P}$ & $\begin{array}{c}\text { Normed } \\
\boldsymbol{\chi} \mathbf{2}\end{array}$ & $\mathbf{G F I}$ & AGFI & $\mathbf{N F I}$ & $\mathbf{T L I}$ & CFI & RMR & RMSEA \\
\hline $\begin{array}{l}\text { Organizational effectiveness- } \\
\text { Employee involvement }\end{array}$ & 388.577 & 149 & .000 & 2.608 & .923 & .845 & .926 & .911 & .952 & .392 & .066 \\
\hline
\end{tabular}

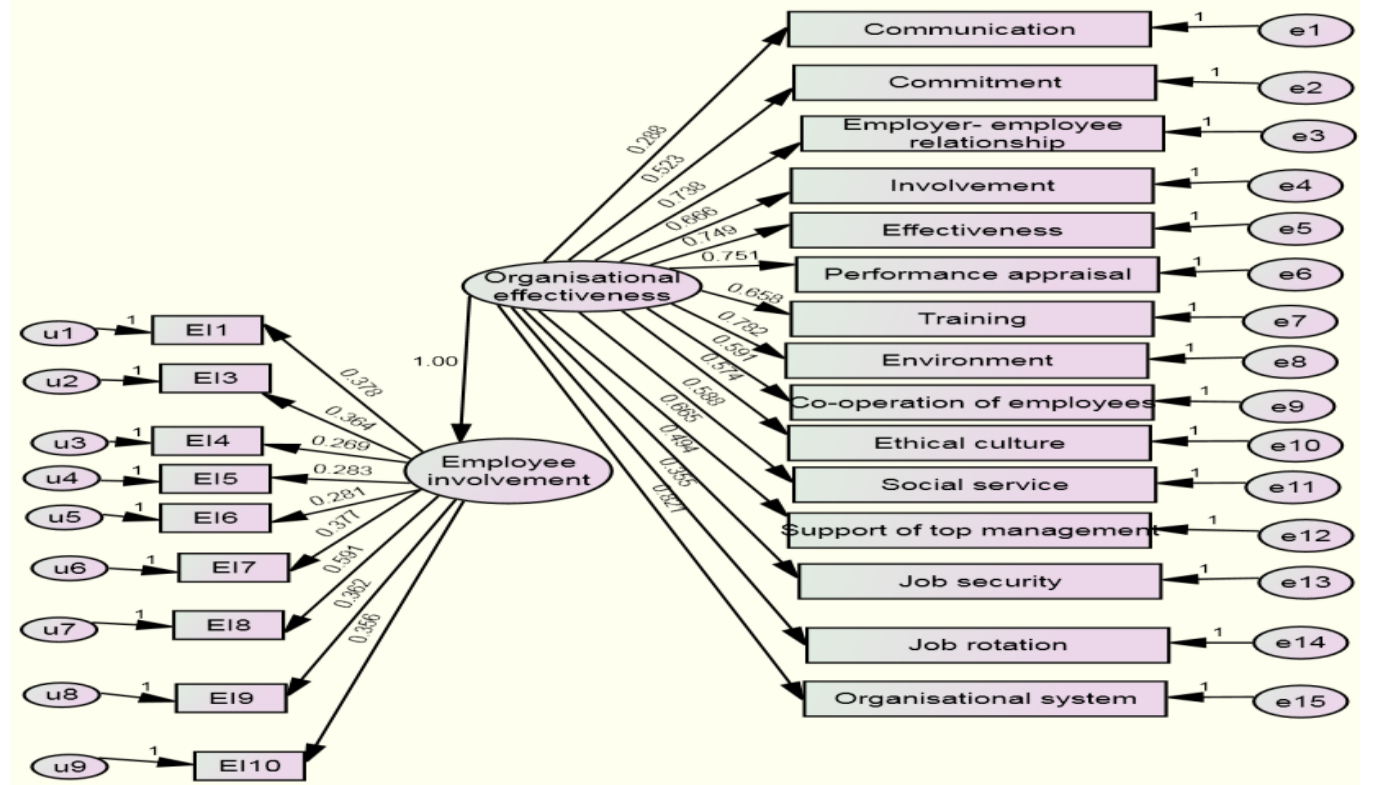

The AMOS 18.0 graphics revealed the correlation of the factors employee involvement and organizational effectiveness. According to the table, the employee involvement and organisational effectiveness have perfect correlation with each other with a value of 1 . In the case of employee involvement, the variable selfachievement has highest correlation with employee involvement because its value is 0.591. Similarly, in the case of organizational effectiveness, the variable organizational system has a highest correlation with organizational effectiveness, with a value of 0.821 .

\section{RESULTS}

When analyzing the factors affecting employee involvement, from the $\chi^{2}$ test of model fit ${ }^{\text {it }}$ is clear that value of chi square is 24.516, while considering the $\mathrm{p}$ value is .221, GFI .987. AGFI, NFI, TLI and CFI are $.963, .969, .986$ and .994 respectively. For RMR and for RMSEA the values are .031 and .025 . From the above mentioned details it is clear that all values in the chi square test of goodness of fit perfectly matches with the standards recommended for each values. That means the model proposed is good and acceptable.

By analyzing the factors affecting organizational effectiveness, the model fit revealed that, 107.697 is the chi-square value and the $p$ value is 0.000 . The value of GFI, AGFI, NFI, TLI and CFI.966, .918, $.970, .969$ and .985 respectively. .296 and .049 are be the value of RMR and RMSEA. So it revealed that, the proposed model it acceptable.

By analyzing the factors affecting organizational effectiveness, the model fit revealed that, 107.697 is the chi-square value and the $p$ value is 0.000 . The value of GFI, AGFI, NFI, TLI and CFI.966, $.918, .970, .969$ and .985 respectively. .296 and .049 are be the value of RMR and RMSEA. So it revealed that, the proposed model it acceptable.

\section{DISCUSSION}

Involvement is the process of building human capacity, ownership and responsibility. Employee involvement is also called participative management and it refers to the degree to which employees share information, knowledge, rewards and 
power throughout the organization. After conducting the research, the proposed that, motivation is the important factor which can enable an employee to work hard to meet organizational goals and to be more effective to involvement, the bank has to consult with its employee about the organizational plans and policies and also promote their self-knowledge and selfachievements. The study further added that, if the bank ready to make more importance to communication, work environment, training programs etc. it can attain more committed employees and can achieve the effectiveness in the market.

\section{CONCLUSION}

Indian banks experienced an extraordinary growth in the past decades with the introduction of economic reforms. To be more profitable, the bank has become more competitive and customer oriented. For getting consumers regularly the banks have to concentrate on its effectiveness. Effectiveness of every organization depends on the work environment, commitment of employees, job satisfaction and most importantly on employee involvement. Employee involvement is when human being considered as unique not a $\operatorname{cog}$ in a machine and each employee involved in helping the organization to meet its goals. According to the study, training programs is a better tool for increasing effectiveness of the organization.

\section{Acknowledgement: None}

\section{Conflict of Interest: None}

\section{Source of Funding: None}

\section{REFERENCES}

1. Amah, E. and Ahiauzu, A. (2013), "Employee involvement and organizational effectiveness", Journal of Management Development, Vol. 32 No. 7, pp. 661674. https://doi.org/10.1108/JMD-092010-0064

2. Bond, S. (2004), "Organisational culture and work-life conflict in the UK",
International Journal of Sociology and Social Policy, 24(12),124. https://doi.org/10.1108/0144333041079 0795

3. Sheehan, C. and Cooper, B.K. (2011), "HRM outsourcing: the impact of organisational size and HRM strategic involvement", Personnel Review, Vol. 40 No. 6, pp. 742-760. https://doi.org/10.1108/0048348111116966 1

4. Khalil Darwish, T. and Singh, S. (2013), "Does strategic human resource involvement and devolvement enhance organisational performance?: Evidence from Jordan", International Journal of Manpower, Vol. 34 No. 6, pp. 674-692. https://doi.org/10.1108/IJM-01-2012-0003

5. Boachie-Mensah, F.O., \& Dogbe, O.D. (2011). Performance-Based Pay as a Motivational Tool for Achieving Organisational Performance: An Exploratory Case Study. International Journal of Biometrics, 6, 270.

6. Gupta, A., Arora, C. (2013, December) Banking sector reforms in India: Impact and prospects. International Journal of Applied Financial Management Perspectives, 2(4), 718-726.

7. Judeh, Mahfuz. (2011). An Examination of the Effect of Employee Involvement on Teamwork Effectiveness: An Empirical Study. International Journal of Business and Management. 6. 10.5539/ijbm. v6n9p202.

8. Lawler, Edward E, III. (2009, October) Employee involvement makes a difference. The Journal for Quality and Participation, 22(5), 18-21

9. Lyons, L., \& Vivenzio, A. D. (1998). Employee Involvement in Seattle: Reengineering Government in a City

10. Lacking a Financial Crisis. Public Personnel Management, 27(1), 93-101. https://doi.org/10.1177/0091026098027001 09

11. Mohsan, F., Nawaz, M.M., \& Khan, M.S. (2012). Impact of job rotation on employee motivation, commitment and job involvement in banking sector of Pakistan. African Journal of Business Management, 6 (24), 7114-7119.

12. Nandan, S., \& Verma, A. (2013). Organizational Change Effectiveness in an Indian Public Sector Organization: 
Kochuthresia Mathew et.al. Impact of employee involvement on organizational effectiveness in the banking sector in Kerala

Perceptions of Employees at Different Levels. South Asian journal of management, 20(1), 97-113.

13. Nankervis, Alan \& Stanton, Pauline \& Foley, P.. (2012). Exploring the rhetoric and reality of performance management systems and organisational effectiveness - Evidence from Australia. Research and Practice in Human Resource Management. 20(1). 4056.

14. Sarangi, S.(2012, March). An exploratory Study of Employee Engagement Initiatives in the Indian Banking Sector. SIES Journal of Management, 8(1), 9-22.

15. Srivastava, S. (2009). Locus of Control as a Moderator for Relationship between Organisational Role Stress and Managerial Effectiveness. Vision, 13(4), 49-61. https://doi.org/10.1177/0972262909013004 05

16. Tesluk, Paul \& Vance, Robert \& Mathieu, John. (1999). Examining Employee Involvement in the Context of Participative
Work Environment'. Group \& Organization Management-GROUP ORGAN MANAGE. 24(3). 271-299. 10.1177/ 1059601199243003.

17. Toomy, K (2006) Employee Involvement Teaming in the Material Review and Corrective Action Group.

18. California State University, UMI Dissertation Publishing.

19. Zwick, Thomas \& Wolf, Elke. (2008). Reassessing the Productivity Impact of Employee Involvement and Financial Incentives. Schmalenbach Business Review (sbr). 60. 160-181. 10.1007/BF03396764

How to cite this article: Mathew $\mathrm{K}$, Resmi R. Impact of employee involvement on organizational effectiveness in the banking sector in Kerala. International Journal of Research and Review. 2021; 8(10): 263-270. DOI: https://doi.org/10.52403/ijrr.202110035 